\title{
Compositional, Structural, Surface Characterizations of Natural Magnetite from Air Massif (Niger) in Relation to Its Catalytic Activity
}

\author{
Mamane Souley Abdoul Aziz ${ }^{1,2}$, Adouby Kopoin², Ousmane Mahamane Sani ${ }^{3}$ \\ ${ }^{1}$ Département d'Energie Fossile, Institut Universitaire de Technologie, Université d'Agadez, Agadez, Niger \\ ${ }^{2}$ LAPISEN, Ecole Doctorale Polytechnique, INPHB, Yamoussoukro, Cote d'ivoire \\ ${ }^{3}$ Département de Chimie, Faculté des Sciences et Technique, Université d'Agadez, Agadez, Niger \\ Email: maman15abdoulaziz@yahoo.com
}

How to cite this paper: Aziz, M.S.A., Kopoin, A. and Sani, O.M. (2020) Compositional, Structural, Surface Characterizations of Natural Magnetite from Air Massif (Niger) in Relation to Its Catalytic Activity. Journal of Minerals and Materials Characterization and Engineering, 8, 197-204. https://doi.org/10.4236/jmmce.2020.84013

Received: May 15, 2020

Accepted: June 14, 2020

Published: June 17, 2020

Copyright $\odot 2020$ by author(s) and Scientific Research Publishing Inc. This work is licensed under the Creative Commons Attribution International License (CC BY 4.0).

http://creativecommons.org/licenses/by/4.0/

\begin{abstract}
Ferrimagnetic materials such as natural magnetite are used for practical applications because of their electronic, magnetic and catalytic properties in the degradation of organic compounds. In order to determine its physicochemical properties in relation to its catalytic activity, the natural magnetite of Ofoud Mount (Niger) is characterized by X-ray florescence (XRF), X-ray diffraction (DRX), specific surface area (BET) and Fourier transformed infrared (FTIR). The result shows an iron content of $97.09 \%$ and a specific surface area of $69.742 \mathrm{~m}^{2} / \mathrm{g}$. The crystal structure of magnetite is cubic with lattice parameters $\alpha=\beta=\gamma=90^{\circ}, \mathrm{a}(\AA)=\mathrm{b}(\AA)=\mathrm{c}(\AA)=8.3740$. The results of this study suggest that the natural magnetite of Ofoud Mount can be used as iron source in various fields of science despite the presence of a few impurities that can improve its catalytic activity.
\end{abstract}

\section{Keywords}

Magnetic, Mineral Composition, Structural, Surface Area

\section{Introduction}

Ferrimagnetic materials such as natural magnetite are used widely in various fields of science because of their electronic, magnetic and catalytic properties [1] [2] [3]. Characterized by a magnetic susceptibility which allows their recovery after use, natural magnetite, magnetite fixed on a support and ferromagnetic nanoparticles are used as catalysts in environmental remediations because of 
their stability [4] [5] [6]. According to H. He et al. [7], natural magnetite exhibits catalytic performance superior to the pure synthetic magnetite. It also contains ferrous and ferric ions which improve its catalytic activity more than other ferromagnetic materials such as hematite and goethite which contain only ferric ion [8]. Due to its redox properties, magnetite offers high activity in the oxidation process of many non-biodegradable organic compounds (pentachorophenol, phenol, polycyclic aromatic compounds PAHs) [9] [10]. Magnetics are ideal for treating soil contaminating with hydrocarbons through the heterogeneous Fenton reaction [11]. Many studies have demonstrated that the capacity of raw rocks rich in magnetite to adsorb and degrade pollutants is largely dependent on their mineral structure and composition [12]. It specifically depends on parameters such as the presence of impurities, the specific surface area, the oxidation state. The chemical composition of magnetite also varies from one iron ore to another, which gives it variable chemical properties [13]. The characterization of each raw rock is therefore essential for a better understanding of its properties and its use. Previous studies on general characterization have been carried out on raw rocks rich in magnetite [14], on purified materials [15] and synthesized magnetite [6]. The aim of this study was to characterize the iron mineral rich in magnetite collected from the Air massif at Ofoud Mount in relation to its catalytic activities.

\section{Material and Methods}

The natural materials rich in magnetite used in this study was collected from the Air massif at Ofoud Mount [5]. These materials have been characterized after grinding and sieved through a mesh to obtain an average size of $0.05 \mathrm{~mm}$ [16]. The mineral composition of the raw magnetite was generated by X-ray fluorescence (XRF), the mineralogical analysis was done with the X-ray diffraction method (XRD) and the specific surface area by the standard BET method.

\section{Result and Discussion}

\subsection{Mineral Composition}

The raw rock content (Table 1) indicated that iron is dominated by $97.09 \%$ (considered as $\mathrm{Fe}_{3} \mathrm{O}_{4}$ ) indicating a probable high content of magnetite and a low content of impurities. It is thus mainly composed of iron with trace elements ( $\mathrm{Ti}, \mathrm{Ni}, \mathrm{Co}, \mathrm{Mn}, \mathrm{Al}$ and $\mathrm{Mg}$ ). These elements had already been found in natural magnetite by Razjigaeva et al., 1992 [9]. Previous studies on synthetic magnetite have shown that the incorporation of $\mathrm{Mn}, \mathrm{Co}, \mathrm{V}$, and $\mathrm{Cr}$ enhances the heterogeneous catalytic activity in the degradation of organic pollutants by hydrogen peroxide [3] [10] [17] [18]. The chemical composition of the raw rock proves that it can be used as iron source in various fields of science. Some studies have shown that $\mathrm{Ni}$ has an inhibitory effect in the catalytic activity of the magnetite [19]. In the magnetite characterized in this study Ni content is very low. 


\subsection{Structural Properties}

The physical and chemical properties of natural magnetite depend also on its structure. The crystal structure and unit parameters of magnetite were studied at room temperature using an Empyreal X-ray diffractometer. The Mount Ofoud magnetite diffractogram is shown in Figure 1.

The XRD pattern is characterized by several reflections (Figure 1), the most intense occurred at the Position [ $\left.{ }^{\circ} 2 \mathrm{Th}.\right]=43.1763$. Figure 1 showed intense and sharp diffraction peaks attesting a high degree of crystallization [20]. The XRD measurements indicated that magnetite was the only crystalline phase detected despite the presence of the minor elements obtained by XRF analysis. Its structural formula is $\mathrm{Fe}_{24 \cdot 00} \mathrm{O}_{32.00}$ with scale fac of 0.773 . The presence of a single phase can be explained by the fact that in natural magnetite, divalent cations (Co, $\mathrm{Ni}, \mathrm{Zn}, \mathrm{Cu}, \mathrm{Mn}$, etc.), trivalent cations ( $\mathrm{Al}, \mathrm{V}, \mathrm{Cr}$, etc.) and tetravalents (Ti) can substitute isomorphically for iron cations without modifying the reverse

Table 1. Chemical composition of the raw rock.

\begin{tabular}{ccc}
\hline \multirow{2}{*}{ Elément } & \multicolumn{2}{c}{ Raw Rock } \\
\cline { 2 - 3 } & Ppm & Percent (\%) \\
\hline $\mathrm{Co}$ & 1331.53 & 0.207631848 \\
$\mathrm{Ni}$ & 2007.27 & 0.313003221 \\
$\mathrm{Fe}$ & $622,636.38$ & 97.09067165 \\
$\mathrm{Mn}$ & 168.84 & 0.02632803 \\
$\mathrm{Ti}$ & 4154.81 & 0.647879415 \\
$\mathrm{Mg}$ & 2177.01 & 0.339471592 \\
$\mathrm{TOTAL}$ & $632,475.84$ & 100 \\
\hline
\end{tabular}

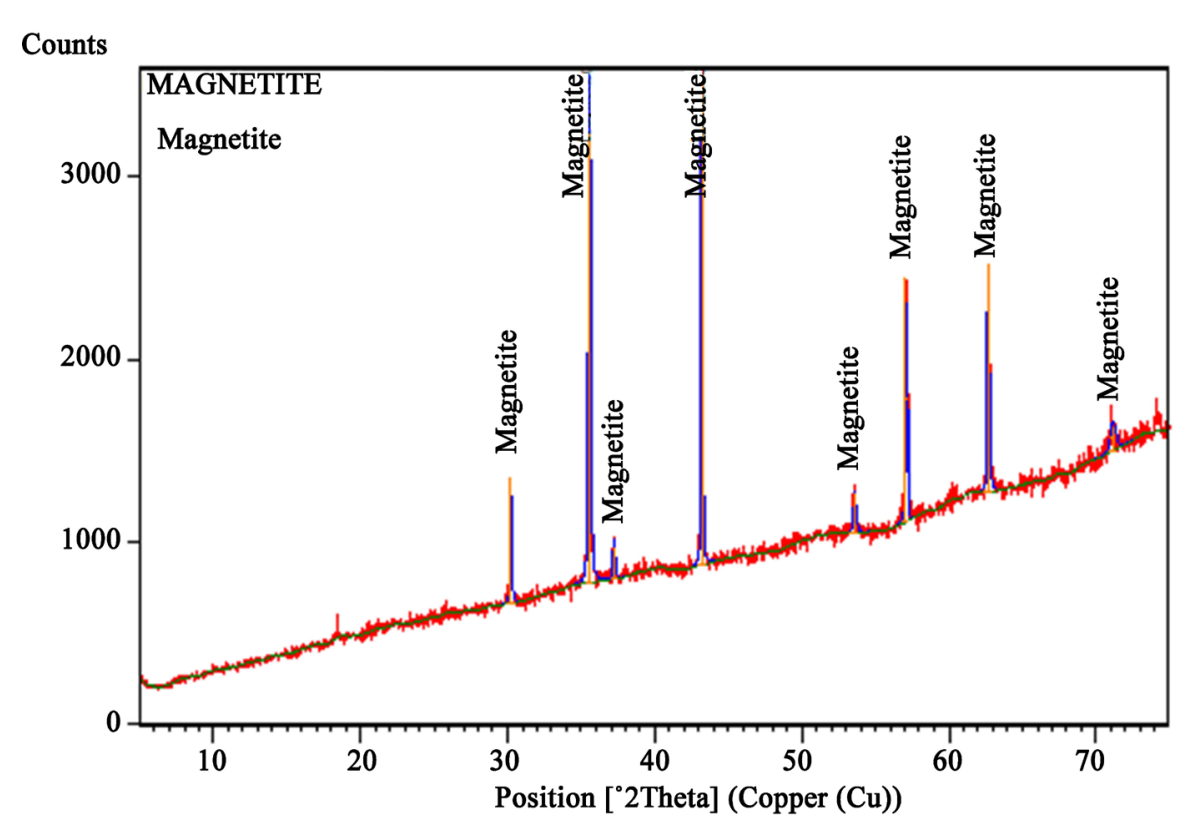

Figure 1. Magnetite diffractogram. 
spinel structure [3] [17]. According to Zhong et al. [21] with the increase of titanium content in the magnetite, the average particle size decreases and the size distribution becomes narrow. The low intensity peak at the position [ $\left.{ }^{\circ} 2 \mathrm{Th}.\right]=$ 18.336 can thus be linked to the presence of titanium in the magnetite. The crystal structure of magnetite is cubic with lattice parameters $\alpha=\beta=\gamma=90^{\circ}$, a $(\AA)=$ $\mathrm{b}(\AA)=\mathrm{c}(\AA)=8.3740$. The only magnetite phase detected crystalize in the Fd-3m with space number 227 [22]. The fit was satisfactory for the $\mathrm{Fe}_{3} \mathrm{O}_{4}$ phase after introducing the atom coordinates (Table 1). Its density of $5.24 \mathrm{~g} / \mathrm{cm}^{3}$ was appropriate with previous research [23]. The result of the DRX analysis shows the chemical purity of this natural magnetite.

\subsection{Specific Surface}

In the heterogeneous Fenton process, the reaction between ferrous or ferric ions and hydrogen peroxide the active sites are located on the surface of the catalyst [24] [25]. The specific surface of the magnetite was determined by N2-BET multipoint analysis using a Novantin kantachrome type surface analyzer.

As can be seen in Table 3, eight methods were used to determine the surface area of the magnetite. Among these analyses, BET is the most popular which has been successfully proved in evaluating the specific area of materials. The main surface area was determined to be $69.742 \mathrm{~m}^{2} / \mathrm{g}$ with Multi Points BET (Figure 2). The relatively high value obtained by adsorption of nitrogen on the magnetite powder is similar to other researches Gorski et al. [22] for a synthetic magnetite. Compared to the specific surface of pure magnetite obtained by several authors, this surface is relatively high [26] [27]. The high value may be related to the presence of titanium in the magnetite because it is approximately equal to the titanomagnetite surface area obtained by Zhong et al. [21]. During the heteroge-

Table 2. Atom coordinates of $\mathrm{Fe}_{3} \mathrm{O}_{4}$.

\begin{tabular}{ccccccccc}
\hline NO. & Name & Element & $\mathbf{X}$ & $\mathrm{Y}$ & $\mathrm{Z}$ & Biso & Sof & Wyck \\
\hline 1 & $\mathrm{FE} 1$ & $\mathrm{Fe}$ & 0.37500 & 0.37500 & 0.37500 & 0.8504 & 1.0000 & $8 \mathrm{~b}$ \\
2 & $\mathrm{FE} 2$ & $\mathrm{Fe}$ & 0.00000 & 0.00000 & 0.00000 & 1.0399 & 1.0000 & $16 \mathrm{c}$ \\
3 & $\mathrm{O}$ & $\mathrm{O}$ & 0.24600 & 0.24600 & 0.24600 & 0.7604 & 1.0000 & $32 \mathrm{e}$ \\
\hline
\end{tabular}

Table 3. Comparison on results of surface area by different methods.

\begin{tabular}{cc}
\hline Method & $\mathrm{S}\left(\mathrm{m}^{2} / \mathbf{g}\right)$ \\
\hline Single point BET & $4.320 \mathrm{e}+01$ \\
Multi Points BET & $6.974 \mathrm{e}+01$ \\
Langmuir surface area & $3.644 \mathrm{e}+02$ \\
BJH method cumulative adsorption surface area & $7.990 \mathrm{e}+01$ \\
DH method cumulative adsorption surface area & $8.512 \mathrm{e}+01$ \\
T method external surface area & $6.974 \mathrm{e}+01$ \\
\hline
\end{tabular}




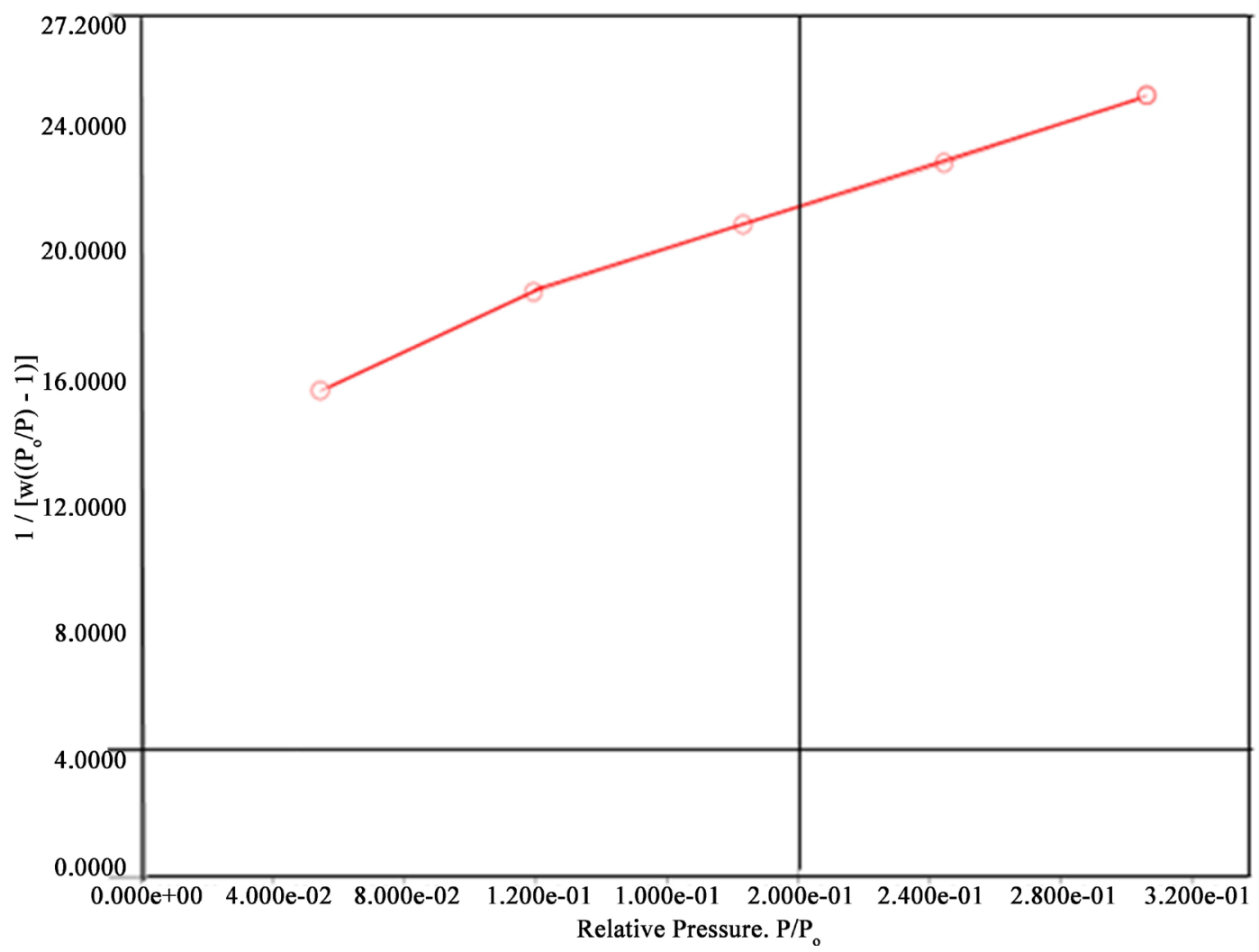

Figure 2. Multipoint BET curve on natural magnetic powders where $\mathrm{P}$ is the measured pressure, $\mathrm{P}^{\circ}$ is the saturated vapor pressure of the adsorbate at the temperature of $77.350^{\circ} \mathrm{K}$.

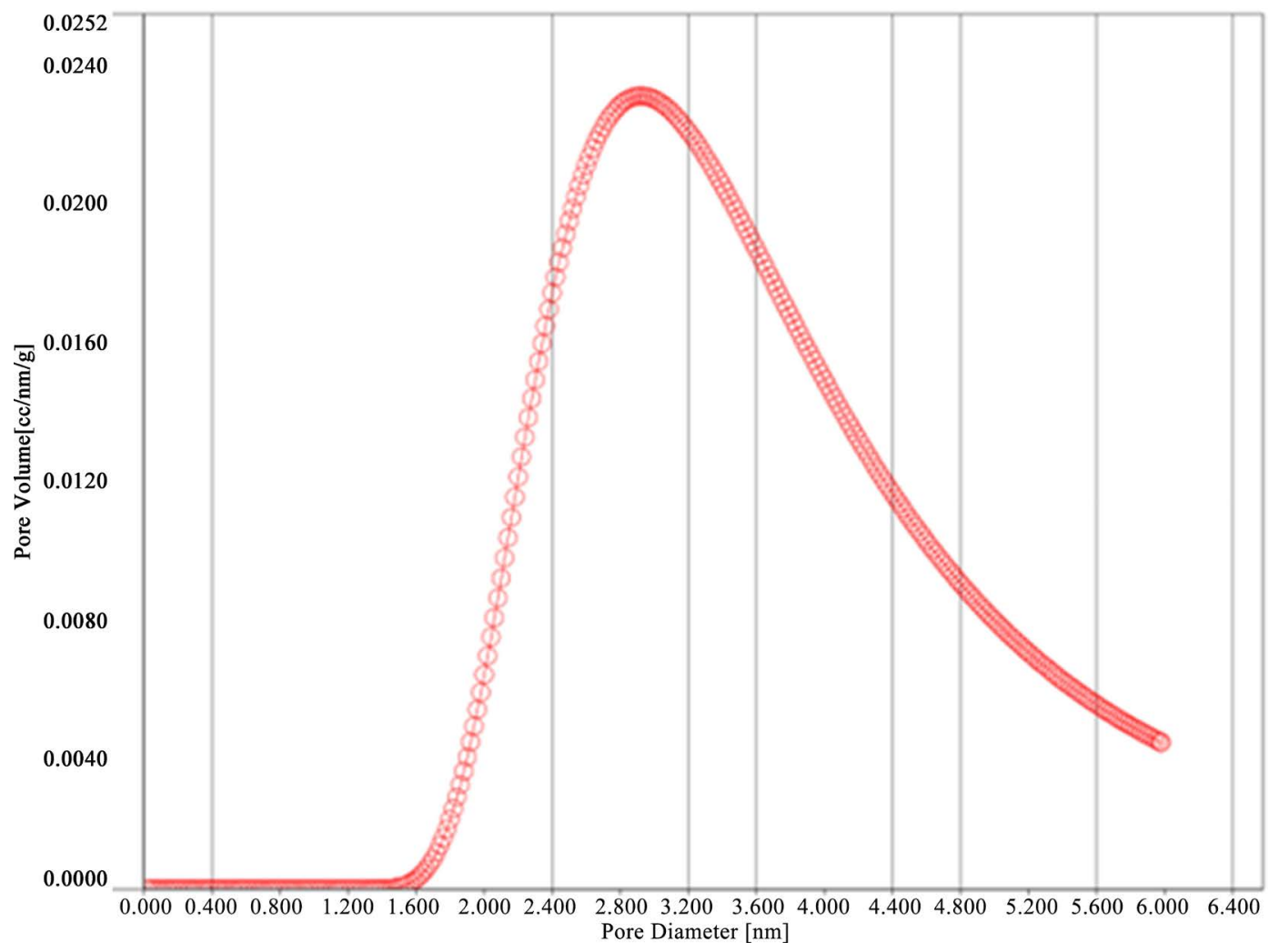

Figure 3. Pore diameter (nm). 
neous Fenton process, the reaction between ferrous and ferric ions with hydrogen peroxide occurs on the surface of the catalyst [25]. The high specific surface of the crushed magnetite can thus favor the oxidation of the adsorbed compounds. The cumulative pore size distribution for magnetite is shown in Figure 3. It shows that the micropores vary from 1.6 to $6.0 \mathrm{~nm}$. The average pore diameter estimated from the peak position is around $2.8 \mathrm{~nm}$ [8]. The most of the pore volume is in the mesoporous range ( 2 to $10 \mathrm{~nm}$ ), showing the strong porous structure of the magnetite. The BET surface area and the average pores diameter values show that it can be used for pollutants adsorption.

\section{Conclusion}

This study demonstrates that the natural magnetite from Ofoud mount is highly pure materials which can be used in various fields of science. The XRD analysis showed that magnetite is the only phase detected despite the presence of traces elements (generated by XRF) that can improve its catalytic activities.

\section{Acknowledgements}

The authors would like to express their sincere and honest gratitude to the Agadez University.

\section{Conflicts of Interest}

The authors declare no conflicts of interest regarding the publication of this paper.

\section{References}

[1] Zhang, L., Dong, W.-F. and Sun, H.-B. (2013) Multifunctional Superparamagnetic Iron Oxide Nanoparticles: Design, Synthesis and Biomedical Photonic Applications. Nanoscale, 5, 7664. https://doi.org/10.1039/c3nr01616a

[2] Makvandi, S., Ghasemzadeh-Barvarz, M., Beaudoin, G., Grunsky, E.C., McClenaghan, M.B., Duchesne, C. and Boutroy, E. (2016) Partial Least Squares-Discriminant Analysis of Trace Element Compositions of Magnetite from Various VMS Deposit Subtypes: Application to Mineral Exploration. Ore Geology Reviews, 78, 388-408. https://doi.org/10.1016/j.oregeorev.2016.04.014

[3] Dupuis, C. and Beaudoin, G. (2011) Discriminant Diagrams for Iron Oxide Trace Element Fingerprinting of Mineral Deposit Types. Mineralium Deposita, 46, 319-335. https://doi.org/10.1007/s00126-011-0334-y

[4] Venkatanarasimhan, S. and Raghavachari, D. (2013) Epoxidized Natural Rubber-Magnetite Nanocomposites for Oil Spill Recovery. Journal of Materials Chemistry $A, 1,868-876$. https://doi.org/10.1039/C2TA00445C

[5] Wang, Q., Zhang, Y., Hu, T. and Meng, C. (2019) $\mathrm{Fe}_{3} \mathrm{O}_{4}$ Nanoparticles/Polymer Immobilized on Silicate Platelets for Crude Oil Recovery. Microporous and Mesoporous Materials, 278, 185-194. https://doi.org/10.1016/j.micromeso.2018.11.033

[6] Usman, M., Hanna, K. and Faure, P. (2018) Remediation of Oil-Contaminated Harbor Sediments by Chemical Oxidation. Science of the Total Environment, 634, 
1100-1107. https://doi.org/10.1016/j.scitotenv.2018.04.092

[7] Hasan, D.B., Abdul Aziz, A.R. and Daud, W.M.A.W. (2012) Oxidative Mineralisation of Petroleum Refinery Effluent Using Fenton-Like Process. Chemical Engineering Research and Design, 90, 298-307. https://doi.org/10.1016/j.cherd.2011.06.010

[8] Wei, Z., Yan, P., Feng, W., Dai, J., Wang, Q. and Xia, T. (2006) Microstructural Characterization of Ni Nanoparticles Prepared by Anodic Arc Plasma. Materials Characterization, 57, 176-181. https://doi.org/10.1016/j.matchar.2006.01.004

[9] Razjigaeva, N.G. and Naumova, V.V. (1992) Trace Element Composition of Detrital Magnetite from Coastal Sediments of Northwestern Japan Sea for Provenance Study. Journal of Sedimentary Research, 62, 802-809. https://doi.org/10.1306/D42679E2-2B26-11D7-8648000102C1865D

[10] Zhong, Y., Liang, X., He, Z., Tan, W., Zhu, J., Yuan, P., Zhu, R. and He, H. (2014) The Constraints of Transition Metal Substitutions ( $\mathrm{Ti}, \mathrm{Cr}, \mathrm{Mn}, \mathrm{Co}$ and Ni) in Magnetite on Its Catalytic Activity in Heterogeneous Fenton and UV/Fenton Reaction: From the Perspective of Hydroxyl Radical Generation. Applied Catalysis B: Environmental, 150-151, 612-618. https://doi.org/10.1016/j.apcatb.2014.01.007

[11] Yang, S., He, H., Wu, D., Chen, D., Ma, Y., Li, X., Zhu, J. and Yuan, P. (2009) Degradation of Methylene Blue by Heterogeneous Fenton Reaction Using Titanomagnetite at Neutral pH Values: Process and Affecting Factors. Industrial \& Engineering Chemistry Research, 48, 9915-9921. https://doi.org/10.1021/ie900666b

[12] He, H., Zhong, Y., Liang, X., Tan, W., Zhu, J. and Wang, C.Y. (2015) Natural Magnetite: An Efficient Catalyst for the Degradation of Organic Contaminant. Scientific Reports, 5, Article No. 10139. https://doi.org/10.1038/srep10139

[13] Dare, S.A.S., Barnes, S.-J., Beaudoin, G., Méric, J., Boutroy, E. and Potvin-Doucet, C. (2014) Trace Elements in Magnetite as Petrogenetic Indicators. Mineralium Deposita, 49, 785-796. https://doi.org/10.1007/s00126-014-0529-0

[14] Fahlepy, M.R., Tiwow, V.A. and Subaer (2018) Characterization of Magnetite $\left(\mathrm{Fe}_{3} \mathrm{O}_{4}\right)$ Minerals from Natural Iron sand of Bonto Kanang Village Takalar for Ink Powder (Toner) Application. Journal of Physics: Conference Series, 997, Article ID: 012036. https://doi.org/10.1088/1742-6596/997/1/012036

[15] Huang, X.-W. and Beaudoin, G. (2019) Textures and Chemical Compositions of Magnetite from Iron Oxide Copper-Gold (IOCG) and Kiruna. Economic Geology, 114, 953-979. https://doi.org/10.5382/econgeo.4651

[16] Usman, M., Faure, P., Ruby, C. and Hanna, K. (2012) Remediation of PAH-Contaminated Soils by Magnetite Catalyzed Fenton-Like Oxidation. Applied Catalysis B: Environmental, 117-118, 10-17. https://doi.org/10.1016/j.apcatb.2012.01.007

[17] Liang, X., He, Z., Tan, W., Liu, P., Zhu, J., Zhang, J. and He, H. (2015) The Oxidation State and Microstructural Environment of Transition Metals (V, Co, and Ni) in Magnetite: An XAFS Study. Physics and Chemistry of Minerals, 42, 373-383. https://doi.org/10.1007/s00269-014-0727-4

[18] Munoz, M., de Pedro, Z.M., Casas, J.A. and Rodriguez, J.J. (2015) Preparation of Magnetite-Based Catalysts and Their Application in Heterogeneous Fenton Oxidation: A Review. Applied Catalysis B: Environmental, 176-177, 249-265. https://doi.org/10.1016/j.apcatb.2015.04.003

[19] Pereira, M.C., Oliveira, L.C.A. and Murad, E. (2012) Iron Oxide Catalysts: Fenton and Fentonlike Reactions-A Review. Clay Minerals, 47, 285-302.

https://doi.org/10.1180/claymin.2012.047.3.01 
[20] Iconaru, S.L., Guégan, R., Popa, C.L., Motelica-Heino, M., Ciobanu, C.S. and Predoi, D. (2016) Magnetite $\left(\mathrm{Fe}_{3} \mathrm{O}_{4}\right)$ Nanoparticles as Adsorbents for As and $\mathrm{Cu} \mathrm{Re}$ moval. Applied Clay Science, 134, 128-135. https://doi.org/10.1016/j.clay.2016.08.019

[21] Zhong, Y., Liang, X., Zhong, Y., Zhu, J., Zhu, S., Yuan, P., He, H. and Zhang, J. (2012) Heterogeneous UV/Fenton Degradation of TBBPA Catalyzed by Titanomagnetite: Catalyst Characterization, Performance and Degradation Products. Water Research, 46, 4633-4644. https://doi.org/10.1016/j.watres.2012.06.025

[22] Cornell, R.M. and Schwertmann, U. (2003) The Iron Oxides: Structure, Properties, Reactions, Occurrences, and Uses. John Wiley \& Sons, Hoboken. https://doi.org/10.1002/3527602097

[23] Néron, A., Dare, S.A.S. and Barnes, S.-J. (2011) Caractérisation géochimique des oxydes de FE-TI dans un dépôt de FE-TI-P associé à la suite anorthositique du Lac-Saint-Jean, Québec, Canada secteur Lac à Paul et intégration des données du secteur Lac à la Mine, Université du Québec à Chicoutimi, module des Sciences de la terre, Chicoutimi. https://constellation.uqac.ca/3462

[24] Gorski, C.A. and Scherer, M.M. (2010) Determination of Nanoparticulate Magnetite Stoichiometry by Mossbauer Spectroscopy, Acidic Dissolution, and Powder X-Ray Diffraction: A Critical Review. American Mineralogist, 95, 1017-1026. https://doi.org/10.2138/am.2010.3435

[25] Garrido-Ramírez, E.G., Theng, B.K.G. and Mora, M.L. (2010) Clays and Oxide Minerals as Catalysts and Nanocatalysts in Fenton-Like Reactions-A Review. Applied Clay Science, 47, 182-192. https://doi.org/10.1016/j.clay.2009.11.044

[26] Javanbakht, V., Ghoreishi, S.M., Habibi, N. and Javanbakht, M. (2017) Synthesis of Zeolite/Magnetite Nanocomposite and a Fast Experimental Determination of Its Specific Surface Area. Protection of Metals and Physical Chemistry of Surfaces, 53, 693-702. https://doi.org/10.1134/S2070205117040086

[27] Xue, X., Hanna, K., Abdelmoula, M. and Deng, N. (2009) Adsorption and Oxidation of PCP on the Surface of Magnetite: Kinetic Experiments and Spectroscopic Investigations. Applied Catalysis B: Environmental, 89, 432-440.

https://doi.org/10.1016/j.apcatb.2008.12.024 